\title{
The antecedents of entrepreneurial intentions in students of Airlangga university (A study of student participants in WEBS in the faculty of economics and business)
}

\author{
P. Yulianti \& I.G.N.W.H. Saputra \\ Universitas Airlangga, Surabaya, Indonesia
}

\begin{abstract}
The number of jobs in Indonesia nowadays is not comparable with the amount of labor, causing high levels of unemployment in the country. This situation has become one of the challenges that must be faced in order to pursue the country's development in a better direction. The government has rightly acknowledged the need to increase its efforts to reduce unemployment levels by creating new jobs or promoting entrepreneurship. The purpose of this research was to explore the influence of the antecedents of entrepreneurial intention among students of Airlangga University. The research used survey methods in relation to 68 student participants in the WEBS activity unit in the Faculty of Economics and Business at Airlangga University. Using a partial least square statistical tool (SmartPLS 2.0, SmartPLS $\mathrm{GmbH}$, Boenningstedt, Germany), the results of the study showed that individual skills aligned with attitudes towards entrepreneurial behavior, perceived environmental dynamism aligned with perceived entrepreneurial behavior control, attitudes towards entrepreneurial behavior aligned with entrepreneurial intentions, and subjective norms aligned with entrepreneurial intentions in positive and statistically significant relationships. However, although the relationships between perceived environmental support and perceived entrepreneurial behavior control, and perceived entrepreneurial behavior control and entrepreneurial intentions were positive, they were not statistically significant.
\end{abstract}

Keywords: Entrepreneurial Intentions, Theory of Planned Behavior

\section{INTRODUCTION}

Nowadays, the number of jobs is not comparable with the amount of labor, which is causing a high level of unemployment in Indonesia. This has become one of the challenges that must be faced by the country in order to pursue the country's development in a better direction. The government has rightly acknowledged the need to increase its efforts in reducing unemployment by creating new jobs and promoting entrepreneurship.

Entrepreneurship is the process of creation and realizing value by entrepreneurs (Morris \& Jones, 1999). Entrepreneurial activities play an important role in improving economic and social development. Entrepreneurship is known to reduce the level of unemployment and increase the welfare of the community through the creation of value in the economy. A country is said to be advanced when it has at least 2 percent of entrepreneurs from the total number of its population, but Indonesia has not yet been able to reach this level.

Becoming an entrepreneur can itself be interpreted as an effort by someone to create jobs by opening a business or creating something new: someone who has been improving the economy for themselves or for other people in the surroundings by becoming an entrepreneur. This course of action has meaningful and significant contributions to the greater good for themselves, those around them, the government and also the country.

Entrepreneurship education has recently become one of the alternative efforts undertaken by the Indonesian government to confront the reality of the current low levels in this area. Both at the school level and in universities, there is a curriculum or educational material related to entrepreneurship. There are also many other programs in addition to formal education, such as entrepreneurship training, seminars, workshops, and so on, which also aim to improve entrepreneurial intentions and the number of entrepreneurs who will later help in improving the economic development of the country.

Entrepreneurship programs implemented at university indirectly raise the young entrepreneurs of Indonesia. The programs were designed in such a way by the Ministry of National Education, through the curriculum and student creativity program with the purpose of creating college graduates 
who are ready to work and create jobs. One of the universities supporting and applying this program is Airlangga University. The university has been advancing the activities of entrepreneurship through supporting students who have talent and interest in the field. The Faculty of Economics and Business, especially, provides support for the entrepreneurship program through a student activity unit called webs through this unit, students get a variety of knowledge, training and motivation that can raise their entrepreneurial intentions.

In the field of entrepreneurship, intention models assume that entrepreneurial behavior is a behavior that is planned, which reflects some degree of cognitive processing, and where intentions are developed in the individual when they elaborate knowledge, trust, attitudes and experiences (Krueger et al., 2000). Many models have been used in previous research to explain and to learn about entrepreneurial intentions, but the most commonly used is the Theory of Planned Behavior (TPB). TPB (Ajzen, 1991) is one of the dominant theoretical frameworks used to analyze the formation of intention in various fields (Armitage \& Conner, 2001), including that of entrepreneurship. There are three variables in TPB that form the factors in determining the intention or behavior: attitude towards the behavior, subjective norm, and perceived behavioral control.

This research will examine the factors that are associated with the formation of entrepreneurial intentions, especially in young people, to become entrepreneurs. The respondents in this research are students who are participants in the WEBS unit in the Faculty of Economics and Business at Airlangga University.

\section{LITERATURE REVIEW}

\subsection{Direct antecedents of entrepreneurial intentions}

The first antecedent of entrepreneurial intentions is attitude toward entrepreneurial behavior. Attitudes are what we feel for a concept (the object of the attitude), a people, brand, ideology, or any other entity that attracts a feeling. In other words, attitude is the evaluation (is it good or bad?) that we give to a certain concept. Attitude is developed from someone's belief, aligned with the object of the attitude. In general, beliefs are formed by associating an object with a specific characteristic or attribute. In relation to attitude towards entrepreneurial behavior, each belief is related to an action or behavior. From the assessment of whether an action is good or bad, we will then determine the extent of the attitude towards the behavior which we have, where, when someone feels that such behavior is beneficial for them, it is then translated into a strong intention to carry out the desired behavior.

The second antecedent of entrepreneurial intentions refers to subjective norms, related to the perception of an entrepreneur on the basis of approval of, or reference to, an individual or group that is important to them in relation to their involvement in the creation of new value through innovative, proactive or risky actions. If attitude illustrates the personal factors that affect the likelihood and willingness of a person to engage in certain behavior, subjective norms illustrate the social factors that affect the individual. In other words, subjective norms are the social pressure that a person feels and faces when he has to decide whether to take an action or behave in a certain way.

The third antecedent of entrepreneurial intentions is perceived entrepreneurial behavior control, namely individual beliefs related to how easy it is for them to create value through involvement in innovative, risky or proactive actions. In general, someone's behavior is influenced by their confidence in their ability to do something. Perceived behavioral control is developed from a belief about either having or lacking control of sufficient resources and opportunities. Such confidence may be based partly on past experience, but will also usually be influenced by secondhand information about the experience of friends and acquaintances, and by other factors that increase or decrease the perceived difficulty associated with performing the corresponding behavior. The more support that is acquired and the smaller it is felt that the obstacles are, the greater is someone's control over entrepreneurial behavior.

Theoretical and empirical results in psychology and sociology have widely confirmed that the attitudes, subjective norms and perceived behavioral control have the ability to predict intention (Armitage \& Conner, 2001). TPB has also received strong support in the domain of management and entrepreneurship, wherein many successful contributions show the predictive validity of the theory in explaining intentions towards entrepreneurship (Kolvereid, 1996; Krueger et al., 2000). From the explanation above, we can draw hypotheses as follows:

H1a: Attitudes (ATT) toward entrepreneurial behavior have a significant effect on a person's entrepreneurial intention (EI).

H1b: Subjective norms (SN) have a significant effect on a person's entrepreneurial intentions.

H1c: Perceived entrepreneurial behavior control (PEBC) has a significant effect on a person's entrepreneurial intentions. 


\subsection{Indirect antecedents of entrepreneurial intentions}

\subsubsection{Antecedents of attitude towards entrepreneurial behavior}

Individual skill. Attitudes can be predicted through cognitive factors such as skills and abilities. This is in line with the assertion by Ajzen and Fishbein (1980), which stated that competencies only impact indirectly on intention, with influences from the factors that closely align with intention (for example, attitudes). In addition, in line with TPB, a person's consciousness of skills and competencies does not directly determine their intention, but influences the degree to which a person develops an assessment (beneficial or otherwise) related to the corresponding behavior. Therefore, lack of awareness about competencies provides a better evaluation of focus on targeted behavior, which indirectly encourages the emergence of intention. Kolvereid (1996) shows that attitudes mediate the relationship between skill and entrepreneurial intentions. In addition, Shapero and Sokol (1982), and Souitaris et al. (2007) also support the premise that individual skills directly impact on attitudes and indirectly influence entrepreneurial intentions. On the basis of this explanation, we propose a hypothesis as follows:

$\mathrm{H}$ 2: Individual skills (IS) have a significant effect on attitudes towards entrepreneurial behavior.

\subsubsection{Antecedents of perceived entrepreneurial behavior control}

Perceived environmental support. When entering the domain of entrepreneurship, some literature has described the importance of external environment in the support of entrepreneurial activity (Fini et al., 2009). Things such as government support, economic status, capital availability, and infrastructure and entrepreneurial support services are able to support and promote entrepreneurial activities. In addition, university support also triggers the emergence of entrepreneurial behavior, principally among students. The existence of environmental support has a positive effect on a person's perception of control in conducting entrepreneurial behavior and affects their confidence in success when applying such behavior.

Perceived environmental dynamism. In addition to the existence of the resources mentioned above, opportunities also influence a person's intentions and actions. The greater the number of opportunities that an individual experiences, the greater their control over the focal behavior (Ajzen, 1991). A dynamic and changing environment allows individuals to better understand, find, or create opportunities. In addition, an active and heterogeneous environment will hone individual innovative and proactive behaviors, and also generate the courage to take risks. From this explanation, we can draw hypotheses as follows:

H3a: Perceived environmental support (PES) has a significant effect on perceived entrepreneurial behavior control.

H3b: Perceived environmental dynamism (PED) has a significant effect on perceived entrepreneurial behavior control.

\section{POPULATION}

The population for this research was student participants in WEBS, a total of 68 people. This population was selected because, in the program, students were supplied with an understanding related to entrepreneurship, so that, in this case, they understand and have some vision related to entrepreneurship.

\section{RESULTS AND DISCUSSION}

\subsection{Relationship between individual skills and attitude toward entrepreneurial behavior}

The hypothesis test results (Table 1) show that there is a positive and significant relationship between individual skills (IS) and attitude (ATT) towards entrepreneurial behavior. In previous research, it has been mentioned that, when a person has awareness of the skills and competencies that they possess, it will have an effect on the degree to which a person develops their assessment (profitable or not profitable) in relation to the corresponding behavior. Therefore, when someone has awareness of their skills and competencies, it gives a better evaluation to focal behavior, which

Table 1. Path coefficients for hypotheses.

\begin{tabular}{llllll}
\hline & $\begin{array}{l}\text { Original } \\
\text { sample } \\
(\mathrm{O})\end{array}$ & $\begin{array}{l}\text { Sample } \\
\text { mean } \\
(\mathrm{M})\end{array}$ & $\begin{array}{l}\text { Standard } \\
\text { deviation } \\
(\mathrm{STDEV})\end{array}$ & $\begin{array}{l}\text { Standard } \\
\text { error } \\
\text { (STERR) }\end{array}$ & $\begin{array}{l}\text { T statis- } \\
\text { tic }(\mid \mathrm{O} / \\
\text { STERR })\end{array}$ \\
\hline $\begin{array}{l}\text { ATT } \\
\rightarrow \text { EI }\end{array}$ & 0.2745 & 0.2743 & 0.0865 & 0.0865 & 3.1743 \\
$\begin{array}{l}\text { IS } \rightarrow \\
\text { ATT }\end{array}$ & 0.3538 & 0.3526 & 0.1341 & 0.1341 & 2.6378 \\
$\begin{array}{l}\text { PEBC } \\
\rightarrow \text { EI }\end{array}$ & 0.0032 & -0.0092 & 0.1252 & 0.1252 & 0.0254 \\
$\begin{array}{l}\text { PED } \rightarrow \\
\text { PEBC }\end{array}$ & 0.3711 & 0.3949 & 0.1009 & 0.1009 & 3.6776 \\
$\begin{array}{l}\text { PES } \rightarrow \\
\text { PEBC }\end{array}$ & 0.1592 & 0.1727 & 0.1063 & 0.1063 & 1.4980 \\
SN $\rightarrow$ & 0.5030 & 0.5107 & 0.0943 & 0.0943 & 5.3357 \\
EI & & & & & \\
\hline
\end{tabular}


indirectly encourages the emergence of intention. Shapero and Sokol (1982), and Souitaris et al. (2007) also support the notion that individual skills have a direct effect on attitudes and an indirect effect on entrepreneurial intentions. When this result is associated with respondents' answers, we can also see that our respondents felt that they had good skills and competencies to take entrepreneurial action, especially in terms of leadership skills, managerial skills and their maturity to take entrepreneurial action.

\subsection{Relationship between perceived environmental support and perceived entrepreneurial behavior control}

The results of the study showed that the relationship between perceived environmental support (PES) and perceived entrepreneurial behavior control (PEBC) is positive, but not significantly so. This result does not support the theory expounded in previous research that stated that external environment support is very important to the support of entrepreneurial activities (Fini et al., 2009). However, when there is good environmental support, such as government support, economic status, capital availability, infrastructure, university support and other entrepreneurial support services, it can support and promote entrepreneurial activities.

\subsection{Relationship between perceived environmental dynamism and perceived entrepreneurial behavior control}

The results of the study showed that the relationship between perceived environmental dynamism (PED) and perceived entrepreneurial behavior control (PEBC) is both positive and significant. The existence of opportunity will affect a person's intent and actions. When a person experiences more opportunities, then they have more control over focal behavior (Ajzen, 1991).

\subsection{Relationship between attitudes toward entrepreneurial behaviour and entrepreneurial intentions}

The results of the study showed that the relationship between attitudes (ATT) towards entrepreneurial behaviour and entrepreneurial intentions (EI) is positive and significant. This result supports the theory expounded in previous research: Eagly and Chaiken (1993) stated that attitude is a psychological tendency of evaluative characteristics that certain parties have, both beneficial or otherwise, aligned with certain behavior, which includes cognitive, affective and conative aspects.

\subsection{Relationship between subjective norms and entrepreneurial intentions}

The results of the study showed that the relationship between subjective norms (SN) and entrepreneurial intentions (EI) is also positive and significant. This result is not in line with the research of Fini et al. (2012). On the other hand, the result supports previous research by Nilsson et al. (2004), which asserts that subjective norms are a construct which explain someone's belief with reference to the influence of other parties in behaving in a certain way, and that becomes the motivation to attain the particular reference behavior.

\subsection{Relationship between perceived entrepreneurial behavior control and entrepreneurial intentions}

The relationship between perceived entrepreneurial behavior control (PEBC) and entrepreneurial intentions (EI) is positive, but not significant. Behavioral control is based on how much someone is willing and able to control their behavior, such that the associated tendencies can be observed, regardless of whether such behavior provides ease or difficulty. If someone's behavioral control is high, then it affords a better opportunity, whereby the individual will be more ready, more optimistic, and more easily able to control the process to start and develop entrepreneurship, and vice versa.

\subsection{Recommendations}

On the basis of these results, researchers recommend the government be more proactive in encouraging and supporting entrepreneurial activities, especially for young people and students. We can see also from this research that government support is very important in increasing the younger generation's intention to become entrepreneurs. Some conditions that need to be revisited are how the government is able to provide assistance, either through ease of access to information, administration and capital assistance, and/or through funding for young people who want to become entrepreneurs. Meanwhile, our recommendations for educational institutions (universities) are to improve on the quality of programs and support, in both the academic and supporting infrastructure for students who show a high interest in entrepreneurship.

We also have recommendations for other academics/researchers who want to continue the research in this field with regard to the limitations of the present research. The small population here was a constraint, making it difficult to generalize. Researchers can also be further developed in future 
academic research is comparison of more concrete explanations related to the formation of entrepreneurial intentions among young people, adopting a wider scope than here by looking at different cultures, backgrounds, and so on. This would more clearly illuminate the formation of entrepreneurial intentions.

\section{REFERENCES}

Ajzen, I. (1991). The theory of planned behavior. Organizational Behavior and Human Decision Processes, 50(2), 179-211.

Ajzen, I. \& Fishbein, M. (1980). Understanding attitudes and predicting social behavior. Englewood Cliffs, NJ: Prentice Hall.

Armitage, C.J. \& Conner, M. (2001). Efficacy of the theory of planned behavior: A meta analytic review. British Journal of Social Psychology, 40, 471-499.

Eagly, A.H. \& Chaiken, S. (1993). The psychology of attitudes. Fort Worth, TX: Harcourt Brace Jovanovich.

Fini, R., Grimaldi, R. \& Sobrero, M. (2009). Factors fostering academics to start up new ventures: An assessment of Italian founders' incentives. Journal of Technology Transfer, 34, 380-402.

Fini, R., Grimaldi, R., Marzocchi, R.G.L. \& Sobrero, M. (2012). The determinants of corporate entrepreneurial intention within small and newly established firms. Entrepreneurship Theory and Practice, 36(2), 387-414.

Kolvereid, L. (1996). Prediction of employment status choice intentions. Entrepreneurship Theory and Practice, 21(1), 47-57.

Krueger, N.F.J., Reilly, M.D. \& Carsrud, A.L. (2000). Competing models of entrepreneurial intentions. Journal of Business Venturing, 15(5), 411-432.

Morris, M.H. \& Jones, F.F. (1999). Entrepreneurship in established organizations: The case of the public sector. Entrepreneurship Theory and Practice, 24(1), 71-91.

Shapero, A. \& Sokol, L. (1982). The social dimensions of entrepreneurship. In C. Kent, D.L. Sexton \& K. Vesper (Eds.), The encyclopedia of entrepreneurship (pp. 72-90). Englewood Cliffs, NJ: Prentice Hall.

Souitaris, V., Zerbinati, S. \& Al-Laham, A. (2007). Do entrepreneurship programmes raise entrepreneurial intention of science and engineering students? The effect of learning, inspiration and resources. Journal of Business Venturing, 22, 566-591. 